\title{
Selections of donors depending on agronomic traits, seed yield components, and fatty acid profile for genetic improvement of Carthamus using stepwise multiple regression
}

\author{
Ahmed A.M. Yassein ${ }^{1,}$, Ahmed E.A. Khalaf ${ }^{2}$, Adel A.A. Mohdaly ${ }^{3}$ and Mohamed H.H. Roby ${ }^{3}$ \\ ${ }^{1}$ Genetics Department, Faculty of Agriculture, Fayoum University, Fayoum 63514, Egypt \\ 2 Agronomy Department, Faculty of Agriculture, Fayoum University, Fayoum 63514, Egypt \\ ${ }^{3}$ Food Science and Technology Department, Faculty of Agriculture, Fayoum University, Fayoum 63514, Egypt
}

Received 13 July 2020 - Accepted 2 October 2020

\begin{abstract}
Safflower (Carthamus tinctorius L.) is of potential interest to agriculture due to mainly variability of fatty acid composition of seeds oil. The purpose of this study was to evaluate various exotic genotypes of safflower for agronomic traits, components of seed yield and fatty acid content. For this purpose, plant height $(\mathrm{cm})$, number of first, second and third branches/plant, seed yield/plant $(\mathrm{g})$, thousandseed weight $(\mathrm{g})$, oil content $(\%)$, and composition of fatty acid were investigated. Stepwise multiple regression analysis was used to develop fitted equation to predicate seed yield/plant. Analysis of variance of agronomic traits showed high differences among genotypes. Although the safflower oil genotype K2 had the highest oil seed content $(42.8 \%)$, K13 obtained the highest percentage of monounsaturated fatty acids (MUFA). Highest oleic type of safflower oil has been found in K13 and K26, which can be used as a source oil quality for plant breeding. Heritability as broad sense was high and ranged from $82 \%$ in number of secondary branches (NSB) and number of third branches (NTHB) to $99 \%$ in seed index (1000 seeds weight) and oil content. High genetic advance was found in plant height (PH), seed yield/plant (SYP) and 1000-seed weight, estimated at $43.41 \mathrm{~cm}, 21.34 \mathrm{~g}$ and $17.62 \mathrm{~g}$, respectively. Stepwise multiple regression analysis indicated that, $99.2 \%$ of the total variation in seed yield/plant could be explained by variation in yield of secondary (YSB) branches, yield of first branches (YFB), yield of third branches (YTHB), plant height (PH) and spiny as dummy variable. $23.56 \%$ of the total variation in seed oil percent could be explained by variation in yield of first branches (YFB), seed index and spiny as dummy variable. The information detected here may be a useful tool for the selection of parents in safflower breeding program.
\end{abstract}

Keywords: safflower / heritability / fatty acid profile / stepwise regression analysis / spiny

Résumé - Sélection de donneurs en fonction des caractéristiques agronomiques, des composantes du rendement et du profil d'acides gras pour l'amélioration génétique du carthame par régression multiple par étapes. Le carthame (Carthamus tinctorius L.) présente un intérêt potentiel pour l'agriculture, principalement en raison de la variabilité de la composition en acides gras de l'huile issus de ses graines. L'objectif de cette étude était d'évaluer divers génotypes exotiques de carthame pour leurs caractéristiques agronomiques, leurs composantes du rendement des graines et leur teneur en acides gras. À cette fin, la hauteur de la plante $(\mathrm{cm})$, le nombre de premières, deuxièmes et troisièmes ramifications/plante, le rendement en graines/plante $(\mathrm{g})$, le poids de mille graines $(\mathrm{g})$, la teneur en huile $(\%)$ et la composition en acides gras ont été étudiés. Une analyse de régression multiple par étapes a été utilisée pour élaborer une équation ajustée permettant de prédire le rendement en graines/plante. L'analyse de la variance des caractères agronomiques a montré de grandes différences entre les génotypes. Bien que le génotype K2 de carthame oléagineux ait eu la plus forte teneur en huile $(42,8 \%)$, le génotype K13 a obtenu le pourcentage le plus élevé d'acides gras monoinsaturés (AGMI). Le type de carthame le plus riche en acide oléique a été identifié dans les génotypes K13 et K26, qui peuvent être utilisés comme sources d'huile de qualité lors de la sélection des plantes. L'héritabilité au sens large était élevée et variait de $82 \%$ sur le nombre de ramifications

*Correspondence: aay00@f ayoum.edu.eg 
secondaires (NSB) et en nombre de ramifications tertiaires (NTHB), à $99 \%$ en indice de graines (poids de 1000 grains) et en teneur en huile. Un progrès génétique important a été constaté en ce qui concerne la hauteur de la plante $(\mathrm{PH})$, le rendement en graines/plante (SYP) et le poids de 1000 grains, estimés respectivement à $43,41 \mathrm{~cm}, 21,34 \mathrm{~g}$ et 17,62 $\mathrm{g}$. L'analyse en régression multiple par étapes a indiqué que $99,2 \%$ de la variation totale du rendement en graines/plante pouvait être expliquée par la variation du rendement des branches secondaires (YSB), du rendement des premières branches (YFB), du rendement des troisièmes branches (YTHB), de la hauteur de la plante $(\mathrm{PH})$ et d'indices de graines et d'épines comme variable fictive. $23,56 \%$ de la variation totale du pourcentage d'huile de graines pourrait être expliquée par la variation du rendement des premières branches (YFB), de l'indice de graines et des épines comme variable fictive. Les informations trouvées ici peuvent être un outil utile pour la sélection des parents dans le programme de sélection du carthame.

Mots clés : carthame / héritabilité / profil des acides gras / analyse de régression par étapes / épineux

\section{Introduction}

Safflower (Carthamus tinctorius L.) is an important cultivated semi-arid oilseed crop, including Egypt. It is worth to note and document that Egypt is suffering dramatically from great shortage in edible oils needed for nutritional consumption. The total local production from plant oils is about $250,000 \mathrm{t}$ and the consumption is about $1,700,000 \mathrm{t}$ in 2017. This indicated that there is a great gap (85.3\%) between production and consumption that has created importation to fulfill the requirements of local market (FAS, 2017). Safflower flowers have been used as a source of textile dyes in Egypt as well as for food and medicinal use (Chapman and Burke 2007). Safflower oil is a valuable vegetable oil seed because it contains a high proportion of oleic and linoleic acid, as well as achieves high quality oil (Khan et al., 2009). Safflower breeding program will improve diversity within species and cultivars (Kemal and Hailu, 2019). The efficiency strategies of plant breeding depend on the inheritance information of the agronomic traits. Genetic improvement would be of interest to safflower-mediated accumulation of desirable parents alleles (Golkar et al., 2012; Kemal and Hailu, 2019). Selection is useful in improving components of yield and in reducing morphological and physiological effects on yield, especially when the traits are highly heritable (Bleidere et al., 2012; Tahernezhad et al., 2018).

Heritability and variance analysis for seed weight, seed yield, oil content and plant height were calculated (Ramachandram and Goud 1981). Safflower (Hamdan et al., 2008) was confirmed to have inherited the very high linoleic acid content. Seed yield and oil content were the most important criteria for improving safflower, so it was important to research the relationship between seed/oil yield before any breeding program was initiated (Hamrouni et al., 2004; Liu et al., 2016).

Safflower oil has different used variously for edible and industrial purposes in recent years. Results of nutritional studies suggested that safflower oil has been promising with high-linoleic and high-oleic oils, and can be blended with other oils (Arslan and Culpan, 2018). Plant selection and genetic improvement depend on the adequate heritable and variation of selected parents used for breeding programs and the nature of the gene action included in expressing the quantitative characters concerned (Acquaah, 2012; Golkar et al., 2017).

Most genotypes of safflower are spiny with many sharp spines on bracts and the leaves (Bradley et al., 1999). Singh (2007) reported that safflower varieties that are almost totally free of spines have been improved for hand harvest in certain geographic zones. Golkar et al. (2010) showed that oil contents of the spiny genotypes are higher than those of the spineless genotypes of safflower. The great shortage in edible oils in Egypt and in world needed improvement in the production and quality of oil plant. The aim of this study was to evaluate various exotic genotypes of safflower for agronomic traits, components of seed yield/plant, genetic components and fatty acid content. Stepwise regression parameters were performed to evaluate and predicate the seed yield/plant and oil percent using quantitative traits (plant height, yield of first, second and third branches/plant, seed yield/plant, 1000-seed weight, oil content) and qualitative trait (spiny as dummy variable).

\section{Materials and methods}

\subsection{Plant material and experimental design}

Exotic safflower genotypes that had been cultivated in earlier experiments conducted at the Demo Farm (Southeast Fayoum; $29^{\circ} 17^{\prime} \mathrm{N} ; 30^{\circ} 53^{\prime} \mathrm{E}$ ), Faculty of Agriculture, Fayoum University, Egypt. Eighteen genotypes of safflower were kindly provided by the gene bank of the United States Department of Agriculture (USDA) for use in this study (Tab. 1). The experiments were conducted during the 2016-2017 and 2017-2018 growing seasons. The genotypes were planted in a randomized complete block design with three replications. Sowing was done by hand in $6 \mathrm{~m}^{2}$ plots, each consisting of five rows, $3 \mathrm{~m}$ in long and $30 \mathrm{~cm}$ apart; plants were $25 \mathrm{~cm}$ apart within rows. Only the three middle rows were harvested (area $3.6 \mathrm{~m}^{2}$ ).

Analysis of variance was performed separately for each individual evaluation trial, and results were combined over the two years. Data measured on the plant characters, plant height $(\mathrm{cm})$, number of first, second and third branches per plant, seed yield/plant (g), 1000-seed weight (g), and oil content (\%) was obtained for each trial. These data were used to derive the genetic parameters, such as genotypic $\left(r^{2} g\right)$ and phenotypic $\left(r^{2} p\right)$ variances, phenotypic coefficient of variation (PCV), genotypic coefficient of variation (GCV), broad-sense heritability $\left(\mathrm{h}_{\mathrm{b}}{ }_{\mathrm{b}}\right)$ and genetic advance $(\mathrm{GA})$, as suggested earlier (Burton, 1952; Johnson et al., 1955).

\subsection{Extraction of crude oil from seeds}

Safflower seeds were carefully cleaned to remove any foreign matter and dried to appropriate moisture and then 
Table 1. Accession number and growth habit of 18 genotypes of safflower.

\begin{tabular}{llll}
\hline Genotype & Accession number PI & Species & Growth habit \\
\hline K1 & 613546 & Carthemus tinctorius & Winter, spiny \\
K2 & 237540 & Carthemus tinctorius & Winter, spiny \\
K4 & 613256 & Carthemus tinctorius & Winter, spineless \\
K5 & 613463 & Carthemus tinctorius & Winter, spineless \\
K6 & 613461 & Carthemus tinctorius & Winter, spiny \\
K7 & 239226 & Carthemus tinctorius & Winter, spiny \\
K8 & 613363 & Carthemus tinctorius & Winter, spiny \\
K9 & 250718 & Carthemus tinctorius & Winter, spineless \\
K12 & 601166 & Carthemus tinctorius & Winter, spiny \\
K13 & 601446 & Carthemus tinctorius & Winter, spineless \\
K15 & 601546 & Carthemus tinctorius & Winter, spineless \\
K17 & 250921 & Carthemus tinctorius & Winter, spiny \\
K19 & 613467 & Carthemus tinctorius & Winter, spiny \\
K21 & 560162 & Carthemus tinctorius & Winter, spiny \\
K24 & 603206 & Carthemus tinctorius & Winter, spiny \\
K25 & 138430 & Carthemus tinctorius & Winter, spiny \\
K26 & 601615 & Carthemus tinctorius & Winter, spiny \\
K27 & 610263 & Carthemus tinctorius &
\end{tabular}

crushed by blender (type IKA A 11 basic). Oil extraction by a conventional method was performed. The crushed seeds were soaked in purified n-hexane for 24 hours at room temperature. The miscella was separated from the cake by filtration with Whatman No. 1 filter paper. This process was repeated 3 times. The filtrate miscella was combined and the oil was then recovered by evaporating the $n$-hexane solvent, under vacuum at $50{ }^{\circ} \mathrm{C}$, by using a rotary evaporator (type Buchi R-114). The obtained oil was dried over anhydrous sodium sulfate, the mass of the oil was quantified by the gravimetric method and then stored in dark brown bottles at $-20{ }^{\circ} \mathrm{C}$ until analysis (Velioglu et al., 2017).

The experimental assays were completely randomized and performed in triplicates.

\subsection{Gas chromatography analysis of oils}

Fatty acid profile of oil samples were determined by using gas chromatography (GC), after initial derivatization to form fatty acid methyl esters (FAME). Methyl esters of fatty acids were prepared in accordance to the method of Mohdaly et al. (2015). Briefly, $100 \mathrm{mg}$ sample adding $1 \mathrm{~mL} \mathrm{BF3/methanol}$ $(14 \%)$ and $1 \mathrm{~mL}$ hexane. The tube then vortexed and placed under nitrogen for $60 \mathrm{~min}$ at $100^{\circ} \mathrm{C}$. Esters of fatty acids were extracted by adding $1 \mathrm{~mL}$ of hexane and washing with $2 \mathrm{~mL}$ of distilled water. After the centrifugation step (4500 rpm, $10 \mathrm{~min}$, $20^{\circ} \mathrm{C}$ ), the supernatant is recovered in vials and then injected into the GC column according to the method described by Mohdaly et al. (2015). The GC instrument (GC-type CG-2010 Plus, Shimadzu) was equipped with a flame ionization detector and a capillary column of $60 \mathrm{~m}$ length, $0.25 \mathrm{~mm}$ internal diameter. The thickness of the film is 0.20 microns was used for analysis. The samples were separated on the column using helium as the carrier gas with a flow rate of $0.8 \mathrm{~mL} / \mathrm{min}$. The sample was injected in split mode (50:1). The temperature program used in the analysis was to keep the unit at $120^{\circ} \mathrm{C}$ for
$2 \mathrm{~min}$ and then climb to $180^{\circ} \mathrm{C}$ for 2 min and the sample was kept at $220^{\circ} \mathrm{C}$ for $25 \mathrm{~min}$. The peak integration is done on the software GC, and the peaks were identified based on comparing retention times with standard fatty acids. Resultant values of fatty acid composition were expressed with a percentage $(\%, \mathrm{w} / \mathrm{w})$ for all the fatty acids detected.

\subsection{Statistical analysis}

The experimental design used was randomized complete blocks with three replications. Statistical analyses were carried out using IBM $^{\circledR}$ SPSS $^{\circledR}$ (SPSS Inc., IBM Corporation, NY, USA) Statistics Version 25 (2017) for Windows. Data were tests for normal distribution (Shapiro-Wilk's test) (Shapiro and Wilk, 1965; Razali and Wah, 2011). Data were subjected to combined analysis of variance (ANOVA) with $P$-value of $<0.05$ was considered to be statistically significant. Bartlett's test was used to determine the homogeneity of variances for two years before doing a combined analysis. The Bonferroni adjustment correction post-hoc test was used to compare the genotypes means (Abdi, 2007).

\subsection{Multiple regression analysis}

The primary selection criteria for safflower breeding are seed yield/plant and its oil content. To obtain a predicted model of seed yield/plant as dependent variable and seven traits as independent variables, stepwise of multiple regression analysis (Kutner et al., 2005) was employed. Six of seven independent variables used as quantitative traits; YSB, YFB, YTH, PH, oil percent and 1000-seed weight while spiny of leaves used as categorical predictor variable. Stepwise regression was also used in order to determine the most important variables significantly contributed to oil percent as dependent variable. Six independent variables used as quantitative traits; YSB, 
YFB, YTH, PH, seed yield/plant and 1000-seed weight while spiny of leaves used as categorical predictor variable.

Categorical predictor variable spiny of leaves used as predictor in regression analysis of both traits seed yield/plant and the oil percent content by generating predictor variable dummy $($ spiny $=1$ and spineless $=0$ ) to reflect group membership knowledge.

The following indices were used as parameters for determining right variant (Afifi et al., 2004): coefficient of determination $\left(R^{2}\right)$, adjusted coefficient determination $\left(R^{2}\right.$ adj), Variance Inflation Factor (VIF), Durbin-Waston $(d)$ and Mallows prediction (Cp).

\section{Results and discussion}

\subsection{Agro-morphological traits}

Analysis of variance for plant height $(\mathrm{PH})$ shows high differences among genotypes. The $\mathrm{PH}$ has been recorded with values beginning at $67.5 \mathrm{~cm}$ to $\mathrm{K} 27$ and $121.8 \mathrm{~cm}$ to $\mathrm{K} 5$. Notable variation was reported with respect to $\mathrm{PH}$ (Baye and Becker 2005). The analysis of variance illustrated significant differences among genotypes in all traits. The highest values of NSB, SYP and YSB were obtained from the K26 genotype, the highest values of NFB and YFB were obtained from the K6 genotype, the highest values of NTHB and YTHB were obtained from the K8 genotype, the highest values of 1000seed weight was obtained from the $\mathrm{K} 4$ genotype, while the highest values of oil percent was obtained from the K2 genotype (Tab. 2). In this regard, Babaoglu and Guel (2015), Erbas and Baydar (2017), Kose et al. (2018) illustrated high variations of agronomic traits and seed yield among Carthamus tinctorius lines selected.

The oil contents values of the genotypes tested varied from 20.1 and $42.8 \%$ (Tab. 2). The K2 genotype, which is a good source of oil production, recorded the highest oil content of $42.8 \%$, while the lowest oil content was recorded in the K5 genotype at $20.1 \%$. The current study's safflower samples showed higher oil contents than those reported by Arslan and Culpan (2018) who found that the oil content values of the Turkey safflower genotypes' oil content values ranged between 15.58 and $37.42 \%$. In another study implemented by Liu et al. (2016), seed oil content ranged from $20 \%$ to $45 \%$, oil content ranged between 28 and $32 \%$ for the C.tinctorius varieties. The variability could be due to effect of the environmental, variety, genetics or agronomy.

\subsection{Safflower oil fatty acids changes}

The quality of the oil is a considerable consumer concern. Changes in fatty acids are of special importance for the oil quality. The oil's compositions of fatty acids have notable effects on its physical and chemical characteristics and on its frying performance. Thus, in this study, we carried out oil analyses to determine the content of aforesaid fatty acids. The composition of fatty acids of the various genotypes safflower oil is given in Table 3. The findings show that on average, palmitic, stearic, oleic and linoleic acids comprised over $98.6 \%$ of total lipids, and more than $90 \%$ of total fatty acids comprised of those oleic and linoleic acids which are proven to be healthy sources of lipids for human body. Knowing the of oleic and linoleic acid in seed oil is therefore extremely important for characterizing a safflower genotypes, both from an agronomic and an economic point of view. Changes in oleic and linoleic acids content among safflower genotypes were clearer than those in the palmitic and stearic acids.

Table 3 shows that 18:1n-9 oleic fatty acid predominated in the K13 and K26 samples ( 70\%), followed by $18: 2 \mathrm{n}-6$ linoleic acid $(\sim 21 \%)$, and that there was a significant difference between the two genotypes for these fatty acids. They had slightly lower palmitic and stearic acids, but a higher of oleic and linoleic acid content, and a higher monounsaturated fatty acids (MUFA) ratio. In the genotypes of K13 and K26, respectively, these four fatty acids made up 99.18 and $99.27 \%$ of seed oil. The other fatty acids, including myristic (C14:0), palmitoleic (C16:1), arachidic (C20:0) paullinic $(\mathrm{C} 20: 1)$ and behenic $(\mathrm{C} 22: 0)$ ranged from 0.06 to $0.29 \%$ in total. On the other hand, the main fatty acid in seed oil of other genotypes was linoleic unsaturated fatty acid of 75.33 to $84.68 \%$ followed by oleic acid (from 6.76 to $15.87 \%$ ), and palmitic (from 5.10 to $7.63 \%$ ) and stearic (from 1.81 to $6.82 \%$ ) saturated fatty acids, and their differences were significant. La Bella et al. (2019) demonstrated that, with cultivation practices and genotype, safflower does not always have the same fatty acid composition, which varied mainly from year to year. Arslan and Culpan (2018) reported the high variability of the safflower for seed oil fatty acids with an average composition of $44.4 \%$ oleic (from 13.97 to $74.74 \%$ ) and $41.0 \%$ linoleic acid (from 12.21 to $69.83 \%$ ). The fatty acid profile of the genotypes safflower in our study was in agreement with those reported by Camas et al. (2007) who found that high linoleic (75-80\%) and low oleic acids (10 $15 \%$ ) have been determined by some genotypes of safflower, while the other genotypes has determined low linoleic acid $(12-30 \%)$ and high oleic acid (64-83\%).

The linoleic fatty acid is considered essential, as it cannot be synthesized by humans and must be derived from food. Consumption of $18: 2 n-6$ (linoleic acid) is widely thought to be able to reduce LDL and overall cholesterol levels. The highly unsaturated fatty acid of linolenic acid (C18:3) content in seed oil of the samples and the commercial was very low (less than $1.06 \%$ ). The samples content of heavily unsaturated linolenic acid fatty acid (C18:3) in seed oil of and the commercial was very small (less than $1.06 \%$ ).

In linoleic types, the oil stability $(18: 1 / 18: 2)$ of samples varied from 0.08 to 0.21 , in oleic forms from 3.25 to 3.35 . Oils oxidative stability was inversely related to linoleic acid and high oleic types (K13 and K26) should be relatively stable and oxidation-resistant. Based on the results of this study, it can be hypothesized that K13 and K26 genotypes are heterozygote dominant while the others genotypes are homozygote dominant in terms of structure of fatty acid. Safflower oil genotypes $\mathrm{K} 1$ and $\mathrm{K} 9$ were high in erucic acid with $\mathrm{K} 1$ and $\mathrm{K} 9$ values of 3.24 and $2.90 \%$, respectively. The overall levels of this fatty acid is $2 \%$ of total fatty acids, since large levels of erucic acid are harmful to human well-being, and can cause heart harm, according to the US law (Hossain et al., 2019).

The highest proportion of monounsaturated fatty acid (MUFA) in total belongs to the safflower oil genotype K13, while the highest percentage of polyunsaturated fatty acid (PUFA) belongs to the K17 genotype safflower oil. In the 18 genotypes, the proportion of unsaturated fatty acids was 


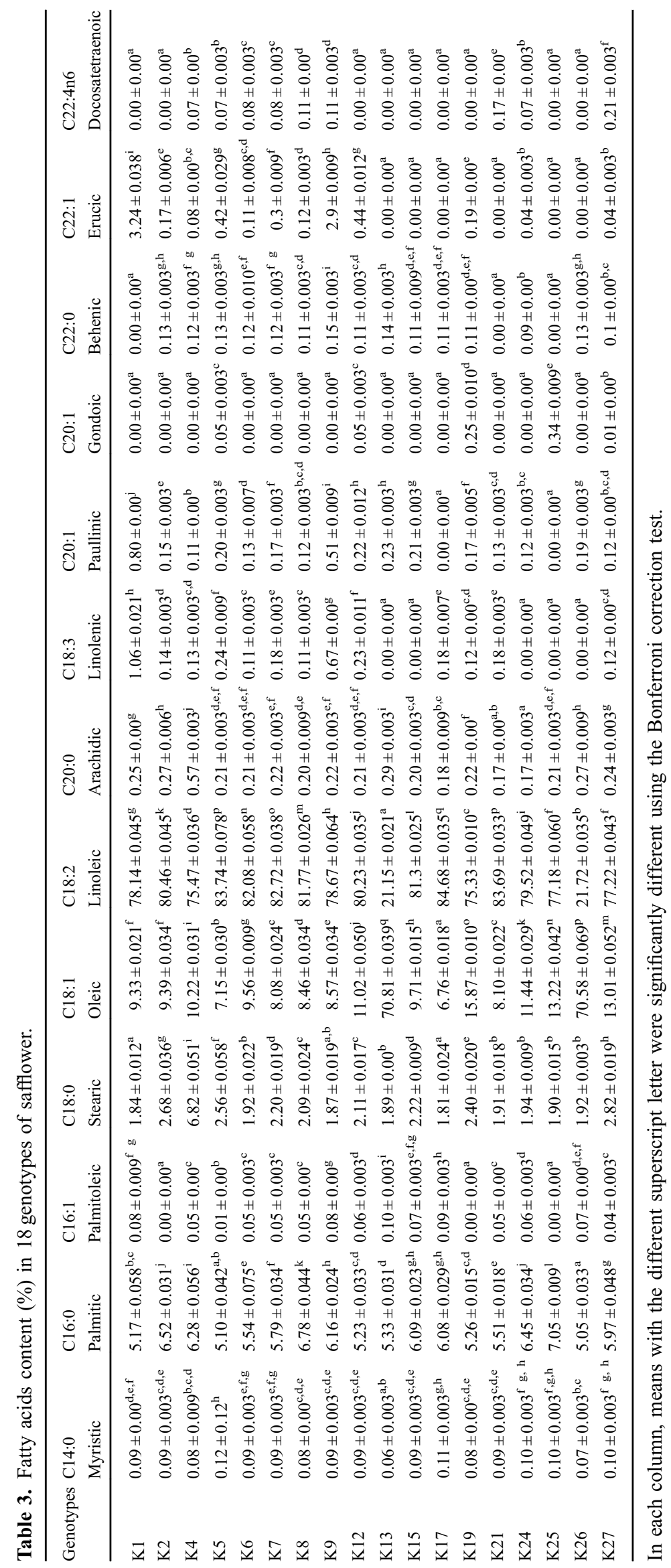




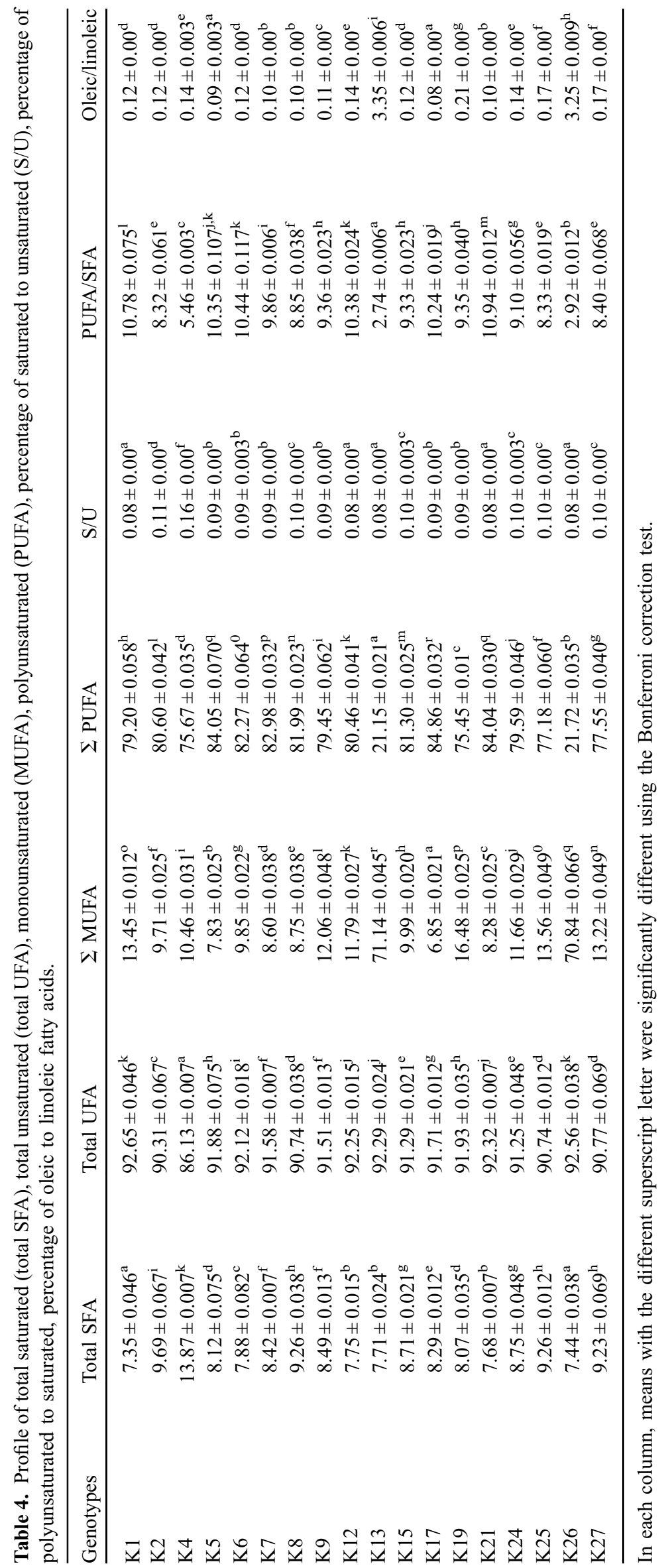


Table 5. Coefficients of variability, heritability in broad sense $\left(\mathrm{h}^{2}\right)$ and expected genetic advance (Gs) for 10 traits of 18 genotypes of safflower.

\begin{tabular}{|c|c|c|c|c|c|c|c|c|c|}
\hline \multirow[t]{2}{*}{$\mathrm{PH}$} & GCV & 21.85 & $h^{2}$ & 93.03 & YFB & GCV & 54.65 & $h^{2}$ & 97.8 \\
\hline & PCV & 22.66 & Gs & 43.41 & & PCV & 55.24 & Gs & 12.52 \\
\hline NFB & GCV & 70.52 & $h^{2}$ & 97.8 & YSB & GCV & 43.45 & $h^{2}$ & 95.4 \\
\hline \multirow[t]{2}{*}{ NSB } & GCV & 33.87 & $h^{2}$ & 82.2 & YTHB & GCV & 148.83 & $h^{2}$ & 90.31 \\
\hline & PCV & 37.44 & Gs & 7 & & PCV & 156.41 & Gs & 5.6 \\
\hline NTHB & GCV & 149.15 & $h^{2}$ & 82.11 & $1000 \mathrm{~S} \mathrm{~W}$ & GCV & 21.28 & $h^{2}$ & 99.9 \\
\hline \multirow[t]{2}{*}{ SYP } & GCV & 35.71 & $h^{2}$ & 95 & Oil & GCV & 15.54 & $h^{2}$ & 99.9 \\
\hline & PCV & 36.46 & Gs & 21.34 & & PCV & 15.55 & Gs & 10.31 \\
\hline
\end{tabular}

$87 \%$ (Tab. 4). The proportions of polyunsaturated fatty acids to saturated fatty acids (PUFA/SFA) also varied within the genotypes. The proportions of saturated fatty acids to unsaturated fatty acids $(\mathrm{S} / \mathrm{U})$, widely used criteria to describe the nutritional value of fat, value was low (from 0.08 to 0.16 ), suggesting their potential as edible sources of oil feed as mentioned by Zahran et al. (2020) who said that the UFA have a favourable effect and positive health benefit than SFA. The fatty acid profile of oil samples in the linoleic types and commercial were almost the same, suggesting the suitability of the seed oil of these genotypes for human use and for industrial purposes. In addition, the high oleic type of safflower oil samples (K13 and K26) are considered very advantageous for health as this class of fatty acids is suitable for hypocholesterol diets, for frying and frozen food preparation. The quality and value of oil production is controlled by fatty acids composition, good oil that is rich in linoleic and oleic acid. Under current study, high variability among safflower genotypes indicated the presence of highly genetic variation, which consider as a good tool for safflower selection and improvement. The principle selection for one trait has the most impact on crops for genetic improvement.

\subsection{Genetic variability, heritability and genetic advance of traits}

Table 5 presents broad sense heritability, genetic advance, genotypic coefficient of variability (GCV), and phenotypic coefficient of variability (PCV). Heritability ranged from $82 \%$ in NSB and NTHB to $99 \%$ in 1000-seed weight and oil content as broad sense (Tab. 5). High estimates of broad-sense heritability for the various traits under study indicate the effect of dominance and/or epistatic variability of control traits may be contributed (Mather and Jinks, 1982).

Application of the breeding selection approach could be more successful for genetic improvement of traits when the heritability value was high (Singh and Pawar, 2005; Mohammadi and Pourdad, 2009).

It has been estimated that high heritability values for plant height and 1000-seed weight suggest these traits are under high genetic control and have been least influenced by environmental effect (Adhikari et al., 2018; Kose et al., 2018; Tahernezhad et al., 2018).

For the majority of traits, the genotypic coefficient of variation (GCV) ranged from 15.54 in oil content to 149.15 in NTHB and phenotypic coefficient of variation (PCV) ranged from 15.55 in oil content to 166.96 in NTHB. Higher GCV than PCV indicates the impact of trait on the environment. The remaining traits recorded GCV values from moderate to low.

The disparity between PCV and GCV reverts to the environmental impact on controlling of traits. High genetic advance when combined with high heritability suggests the role of additive genes in regulating the inheritance of these traits, which could be strengthened by selection (Yassein, 2013; Minnie et al., 2018). Although coefficients of variation measure the magnitude of variability between genotypes, estimates of heritability and genetic advances are important in plant breeding program, as they provide necessary information before designing the most successful breeding program.

\subsection{Estimates of expected genetic advance}

Genetic advances were between 4.1 (NTHB) and 43.41 (PH), with similar findings (Baye and Becker, 2005). Table 5 provides predicted genetic advance values for the characters evaluated of the genotypes. High genetic advance was found in PH, SYP and 1000-seed weight, respectively, 43.41, 21.34 and 17.62. The trait with high heritability and low genetic advance, NTHB and YTHB, suggests the action of non-additive gene and may be not effective successful in selecting early segregating generations as verified by Chand et al. (2008).

The importance of genetic advance and heritability (Johnson et al., 1955) is one of the most important criteria used in selection process. Genetic advance is a useful in explaining the type of genetic influence involved in trait control, whereas high genetic advance value is indicative of an additive gene influence and low values are indicative of nonadditive gene effect. Broad sense heritability of a trait indicates genetic influence among the phenotypes attributed and affected by the environmental impact on the genotypes (Eshghi et al., 2012; Johnson et al., 1955).

\subsection{Stepwise analysis}

Fitted equation, coefficient of determination $\left(R^{2}\right)$, adjusted coefficient determination $\left(R^{2}\right.$-adj), $P$-value, standard error of estimate (SEE), Durbin-Waston $(d)$, Mallows prediction $(\mathrm{Cp})$ and Variance Inflation Factor (VIF) to predicate seed yield/plant and oil percentage of all genotypes are presented in Table 6 . Several models were given as a result of stepwise regression for seed yield/plant and oil percentage prediction. Model 5 best 
Table 6. Summary of stepwise method of multiple regression and indices parameters for predicting seed yield/plant and oil percent of all genotypes under study.

\begin{tabular}{|c|c|c|c|c|c|c|c|c|}
\hline DV & Fitted equation & $R^{2} \%$ & $R^{2}$-adj\% & $P$-value & SEE & Durbin-Waston & Mallows prediction & VIF \\
\hline Seed yield/plant & $\begin{array}{l}\mathrm{Y}=1.85+\left(0.95^{* *} \mathrm{YSB}\right) \\
+\left(0.93^{* *} \mathrm{YFB}\right)+\left(1.02^{* *} \mathrm{YTH}\right) \\
+\left(0.03^{* *} \mathrm{PH}\right)+\left(0.97^{* *} \text { Spiny }\right)\end{array}$ & 99.61 & 99.22 & $* * *$ & 0.96 & 2.36 & 5.2 & $<10$ \\
\hline Oil percentage & $\begin{array}{l}\mathrm{Y}=25.68+\left(0.28^{* *} \mathrm{YFB}\right) \\
+\left(0.19^{* *} \text { Thousand }\right)+\left(3.29^{* *} \text { Spiny }\right)\end{array}$ & 25.61 & 23.56 & $* * *$ & 4.1 & 1.7 & 4 & $<10$ \\
\hline
\end{tabular}

$R^{2} \%$ : coefficient of determination; $R^{2}$-adj: adjusted coefficient determination; SEE: standard error of estimate; $d$ : Durbin-Waston; Cp: Mallows prediction; VIF: Variance Inflation Factor. * and $* *$ significant at the 0.05 and 0.01 level respectively.

predicated seed yield/plant $(\mathrm{Y}=1.85+0.95 \mathrm{YSB}+0.93 \mathrm{YFB}$ +1.02 YTHB $+0.03 \mathrm{PH}+0.97$ Spiny) Table 6 , model 5 among all models for predicting which containing five independent variables YSB, YFB, YTHB, PH and spiny. While model 3 best predicated model among all models for predicting oil percent (Tab. 6) containing three independent variables $(\mathrm{Y}=25.24$ -0.28 YFB $+0.20 \quad 1000$-seed weight +3.31 Spiny) YFB, 1000 -seed weight and spiny. For both models, coefficients 0.97 and 3.31 of the spiny variable indicated that, when each genotype is spineless (equal to one) relative to baseline spineless (equal to zero), the seed yield/plant and percentage of oil increased by $0.97 \mathrm{~g}$ and $3.31 \%$ respectively for spiny genotypes more than spineless genotypes withhold other all independent variables as constant.

Model 5 and model 3 were positively and strongly correlated with seed yield/plant and oil percent, respectively, with high value of $R^{2}$-adjusted (99.66 and $23.56 \%$ respectively), indicating that $99.66 \%$ of the seed yield/plant variance was predictable from those five independent variables, while $23.56 \%$ of variance of oil percent variance was predictable from those three independent variables. Seed yield/plant and oil percentage for model 5 and model 3 ( 0.96 and 4.1, respectively) were observed of low standard error estimate. These findings are consistent with those reported by Choulwar et al. (2005) and Golkar et al. (2010) who reported that plant height, first branch height, number of branches/plant, head diameter, seeds per head and 1000seed weight are the most important morphological characteristics related to seed yield. Results of indices used for testing of both models were showed in Table 6 . Therefore, the value of Variance Inflation Factor (VIF) for both models was VIF $<10$, so there was no multicollinearity issue between independent variables for seed yield/plant and oil percentage. These results promote the identification and intervention of the actual contribution of each independent variable in the each model with negligible confounding effects and interference. The Durbin-Watson analysis for seed yield/ plant and oil percentage $d=2.36$ and 1.7 respectively, which is between the two critical values of $1.5<d<2.5$. Therefore, in both models there is no linear auto-correlation of first order. Lastly, Mallows Cp suggests that model five and model three were relatively precise and unbiased seed yield/plant prediction $(\mathrm{Cp}=5.2)$ and oil percentage $(\mathrm{Cp}=4)$. Those two Mallows' $\mathrm{Cp}$ values were closest to the number of predictors plus the constant (respectively 6 and 4 of the models 3 and 5).

\section{Conclusion}

High variations confirmed between genotypes. Genotype K26 had high NSB, SYP and YSB, while genotype K6 had high NFB and YFB, genotype K8 in NTHB and YTHB, K17 in $\mathrm{HFB}$, genotype $\mathrm{K} 4$ in 1000-seed weight and $\mathrm{K} 2$ in oil percentage. Genotypes K26 and K13 had high safflower oleic and can be used in breeding program. Safflower oil genotypes $\mathrm{K} 1$ and $\mathrm{K} 9$ were high in erucic acid with $\mathrm{K} 1$ and $\mathrm{K} 9$ values of 3.24 and $2.90 \%$, respectively. Most of traits with high heritability that indicate these traits are under high genetic control. High genetic advance in PH, SYP and 1000-seed weight was reported. High heritability coupled with high genetic advance that shows the additive gene effect that controls the inheritance of these traits. Stepwise multiple regression analysis showed that $99.22 \%$ of the total variation in seed yield/plant could be explained by yield of secondary branches (YSB), yields of first branches (YFB), yield of third branches (YTHB), plant height (PH) and spiny as dummy variable. Yields of first branches (YFB), 1000 seed weight and spiny were responded about $23.56 \%$ of total variation of oil percent. Results suggest that yields of first branches (YFB) and spiny as dummy variable are primary selection criteria for improving seed yield/plant and oil percent.

\section{References}

Abdi H. 2007. Bonferroni and Sidak corrections for multiple comparisons. In: Salkind NJ, ed. Encyclopedia of measurement and statistics. Thousand Okas, CA: Sage, pp. 103-107.

Acquaah G. 2012. Priciples of plant genetics breeding. J Chem Inf Model 53(9): 146-170.

Adhikari BN, Joshi BP, Shrestha J, Bhatta NR. 2018. Genetic variability, heritability, genetic advance and correlation among yield and yield components of rice (Oryza sativa L.). J Agric Nat Resour 1: 149-160.

Afifi A, Clark VA, May S. 2004. Computer-aided multivariate analysis. Boca Raton, FL: Chapman \& Hall/CRC.

Arslan B, Culpan E. 2018. Identification of suitable safflower genotypes for the development of new cultivars with high seed yield, oil content and oil quality. Azarian J Agric 5(5): 133-141.

Babaoglu M, Guel M. 2015. Safflower (Carthamus tinctorius L.) breeding activities at Trakya Agricultural. J Crop Breed Genet 1(1): 20-25.

Baye T, Becker HC. 2005. Genetic variability and interrelationship of traits in the industrial oil crop Vernonia galamensis. Euphytica 142: 119-129. 
Bleidere M, Mežaka I, Legzdiņa L, Grunte I, Beinaroviča I, Rostoks N. 2012. Variation of spring barley agronomic traits significant for adaption to climate change in latvian breeding programmes. Proc Latv Acad Sci Sect B Nat Exact Appl Sci 66(1-2): 30-35.

Bradley VL, Guenthner RL, Johnson RC, Hannan RM. 1999. Evaluation of safflower germplasm for ornamental use. In: Janik J, ed. Perspectives new crop new uses. Alexandria, USA: ASHS Press, pp. 433-435.

Burton GW. 1952. Quantitative inheritance in grasses. In: Proc 6th Int Grassl Congr, pp. 277-283.

Camas N, Cirak C, Esendal E, Tarihi G. 2007. Seed yield, oil content and fatty acids composition of safflower (Carthamus tinctorius L.) grown in northern turkey conditions. J Fac Agric OMU 22(1): 98-104.

Chand N, Vishwakarma SR, Verma OP, Kumar M. 2008. Worth of genetic parameters to sort out new elite barley lines over heterogeneous environments. Barley Genetics Newsletter 38: 10-13.

Chapman MA, Burke JM. 2007. DNA sequence diversity and the origin of cultivated safflower (Carthamus tinctorius L.; Asteraceae). BMC Plant Biol 7: 60.

Choulwar SB, Dhutmal RR, Madrap IA, Joshi BM. 2005. Genetic variability for yield and yields related traits in F2 population of safflower. J Maharashtra Agric Univ 30(1): 114-116.

Erbas S, Baydar H. 2017. Aspir (Carthamus tinctorius L.)'de Verim, Yağ ve Oleik Asit İçeriği Yüksek Hat Gelistirme Islahı. Tarla Bitk Merk Arastırma Enstitüsü Derg [Internet] 25(ÖZEL SAYI-2): 155-155. Available from http://dergipark.gov.tr/doi/10.21566/ tarbitderg.281888 (accessed 2020 March 17).

Eshghi R, Abrahimpour F, Ojaghi J, Salayeva S. 2012. Evaluation of genetic variability in naked barley (Hordeum vulgare L.). Int J Agric Crop Sci 4(16): 1166-1179.

FAS. 2017. Foreign Agriculture Service/USDA, Office of Global Analysis, Circular Series FOP 9-2017, September 2017.

Golkar P, Arzani A, Rezaei A. 2012. Genetic analysis of agronomic traits in safflower (Carthamus tinctorious L.). Not Bot Horti Agrobot Cluj-Napoca 40(1): 276-281.

Golkar P, Arzani A, Rezaei AM. 2010. Inheritance of flower colour and spinelessness in safflower (Carthamus tinctorius L.). J Genet 89: 256-262.

Golkar P, Shahbazi E, Nouraein M. 2017. Combining ability $\times$ environment interaction and genetic analysis for agronomic traits in safflower (Carthamus tinctorius L.): biplot as a tool for diallel data. Acta Agric Slov 109(2): 165-173.

Hamdan YAS, Pérez-Vich B, Fernández-Martínez JM, Velasco L. 2008. Inheritance of very high linoleic acid content and its relationship with nuclear male sterility in safflower. Plant Breed 127(5): 507-509.

Hamrouni I, Touati W, Dhifi W, Chahed T, Ayachi S, Salah H, et al. 2004. Glycerolipid evolution during safflower seed formation and ripening. J Food Lipids 11(4): 297-311.

Hossain Z, Johnson EN, Wang L, Blackshaw RE, Gan Y. 2019. Comparative analysis of oil and protein content and seed yield of five Brassicaceae oilseeds on the Canadian prairie. Industrial Crops \& Products 136: 77-86.

Johnson HW, Robinson HF, Comstock RE. 1955. Estimation of genetic and environmental variability in soybean. Agron J 47: 477-482.

Kemal A, Hailu F. 2019. Genetic diversity of Safflower (Carthamus tinctorius L.) genotypes at Wollo, Ethiopia using agro-morphological traits. Trop Plant Res 6(1): 157-165.
Khan MA, Von Witzke-Ehbrecht S, Maass BL, Becker HC. 2009. Relationships among different geographical groups, agro-morphology, fatty acid composition and RAPD marker diversity in Safflower (Carthamus tinctorius). Genet Resour Crop Evol 56(1): 19-30.

Kose A, Onder O, Bilir O, Kosar F. 2018. Application of multivariate statistical analysis for breeding strategies of spring safflower (Carthamus tinctorius L.). Turkish J F Crop 23(1): 12-19.

Kutner MH, Christopher JN, John N, William L. 2005. Applied Linear Statistical Models. New York: McGraw-Hill, pp. 134-137, 256-293, 343-382.

La Bella S, Tuttolomondo T, Lazzeri L, Matteo R, Leto C, Licata M. 2019. An agronomic evaluation of new safflower (Carthamus tinctorius L.) germplasm for seed and oil yields under mediterranean climate conditions. Agronomy 9(8). https://doi.org/10.3390/ agronomy9080468.

Liu L, Guan L-L, Yang Y-X. 2016. A review of fatty acids and genetic characterization of safflower (Carthamus tinctorius L.) seed oil. World J Tradit Chin Med 2(2): 48-52.

Mather K, Jinks J. 1982. Biometrical genetics 3rd ed. London: Chapman and Hall.

Minnie CM, Sandeep S, Sujatha K. 2018. Genetic variability, heritability and genetic advance studies in safflower (Carthamus tinctorius L.). Int J Curr Microbiol App Sci 7(12): 3714-3718.

Mohammadi R, Pourdad SS. 2009. Estimation, interrelationships and repeatability of genetic variability parameters in spring safflower using multi-environment trial data. Euphytica 165(2): 313-324.

Mohdaly AA, Mahmoud AA, Housain MH, Iryna S. 2015. Chemical composition, physicochemical properties and fatty acid profile of Tiger Nut (Cyperus esculentus L) seed oil as affected by different preparation methods. Int Food Res J 22(5): 1931-1938.

Ramachandram M, Goud JV. 1981. Genetic analysis of seed yield, oil content and their components in safflower (Carthamus tinctorius L.). Theor Appl Genet 60(3): 191-195.

Razali NM, Wah YB. 2011. Power comparisons of Shapiro-Wilk, Kolmogorov-Smirnov, Lilliefors and Anderson-Darling tests. J Stat Model Anal 2(1): 21-33.

Shapiro SS, Wilk MB. 1965. An analysis of variance test for normality (complete samples). Biometrika 52(3/4): 591-611.

Singh S, Pawar IS. 2005. Theory and application of biometrical genetics. CBS Press.

Singh RJ. 2007. Genetic resources, chromosome engineering and crop improvement. Boca Raton, USA: CRC Press.

Tahernezhad ZAT, Aba JAS, Einalabedini MEZ. 2018. Estimation of broad-sense heritability and variance components for seed yield and agronomic traits in native and exotic safflower (Carthamus tinctorius L.) genotypes. Bangladesh J Bot 47(3): 501-508.

Velioglu SD, Temiz HT, Ercioglu E, Velioglu HM, Topcu A, Boyaci IH. 2017. Use of Raman spectroscopy for determining erucic acid content in canola oil. Food Chem 221: 87-90.

Yassein AAM. 2013. Selection criteria of donors of some agronomic characters in different barley genotypes. Egypt J Appl Sci 28(12): 424-434.

Zahran HA, Abd-Elsaber A, Tawfeuk HZ. 2020. Genetic diversity, chemical composition and oil characteristics of six sesame genotypes. OCL 27: 39.

Cite this article as: Yassein AAM, Khalaf AEA, Mohdaly AAA, Roby MHH. 2020. Selections of donors depending on agronomic traits, seed yield components, and fatty acid profile for genetic improvement of Carthamus using stepwise multiple regression. OCL 27: 66. 